\title{
MENINGKATKAN KEMAMPUAN KOMUNIKASI MATEMATIS SISWA MELALUI PENERAPAN CREATIVE PROBLEM SOLVING
}

\author{
I.M. Widiatmika I.G.P Suharta, I.P.P. Suryawan \\ Jurusan Matematika Universitas Pendidikan Ganesha \\ Singaraja, Indonesia \\ e-mail: widiw386@gmail.com, igpsuharta@yahoo.com, pasek.suryawan@yahoo.co.id
}

\begin{abstract}
Abstrak
Penelitian ini bertujuan untuk mengetahui: (1) peningkatan kemampuan komunikasi matematis siswa kelas VIIA SMP Negeri 3 Sukasada dan (2) respon siswa terhadap penerapan model pembelajaran creative problem solving. Jenis penelitian ini adalah penelitian tindakan kelas yang dilaksanakan dalam tiga siklus. Subjek penelitian ini adalah siswa kelas VIIA SMP Negeri 3 Sukasada sebanyak 32 siswa pada semester genap tahun ajaran 2018/2019. Data komunikasi matematis siswa dikumpulkan menggunakan tes komunikasi matematis dan tanggapan siswa dikumpulkan menggunakan angket. Data yang telah terkumpul selanjutnya dianalisis secara deskriptif. Hasil penelitian ini menunjukkan bahwa persentase banyaknya siswa dengan kemampuan komunikasi matematis yang berada pada kategori minimal tinggi meningkat dari siklus ke siklus, pada siklus I, siklus II dan siklus III berturut - turut yaitu : $21,87 \%, 46,87 \%$ dan $75 \%$. Peningkatan optimal pada siklus III terjadi karena guru lebih menekankan pada pertanyaan arahan dalam mengemukakan gagasan gagasan, memberikan kebebasan kepada siswa untuk menyelesaikan permasalahan sesuai dengan cara mereka sendiri, memberikan kesempatan lebih banyak kepada siswa untuk menyampaikan pendapat, serta mengevaluasi jalannya diskusi pada akhir pembelajaran. Selain itu respon siswa terhadapa model pembelajaran creative problem solving tergolong positif dengan rata - rata respon siswa sebesar 55,53.
\end{abstract}

Kata kunci: Creative Problem Solving, Komunikasi Matematis, Tanggapan

\begin{abstract}
This study was aimed at investigating: (1) the improvement of mathematical communication skills of VIIA grade students of SMP Negeri 3 Sukasada and (2) students' responses on the implementation of creative problem solving learning model. The design of this study was classroom action research that was conducted in three cycles. The subject of this study was 32 students of VIIA grade of SMP Negeri 3 Sukasada in second semester of academic year 2018/1019. The data of students' mathematical communication were collected by using mathematical communication test, meanwhile the students responses were collected by using questionnaire. The collected data were analysed descriptively. The result of this study showed that the percentage of students with mathematical communication skills in minimum category was improved from cycle to cycle. The percentage in cycle I, cycle II, and cycle III were $21.87 \%, 46.87 \%$, and $75 \%$. The optimum improvement in cycle III occurred because the teacher more emphasised on the directional questions in expressing ideas, gave chance for students to solve problems in their own way, gave chance for students to express their opinions, and evaluated the discussion in the end of the learning process. In addition, students responses on the implementation of creative problem solving learning model were positive with the average 55.53 responses.
\end{abstract}

Keywords : Creative Problem Solving, Mathematical Communication, Response

\section{PENDAHULUAN}

Komunikasi matematika siswa merupakan bagian yang penting dalam proses pembelajaran matematika. Ramdani (2012) menyatakan bahwa komunikasi matematika merupakan suatu kegiatan seseorang berbagi informasi berupa ide - ide matematika baik secara lisan maupun tulisan dalam bentuk simbol, data, grafik ataupun tabel. Melalui komunikasi matematika guru mampu mengetahui kemampuan siswa dalam 
menginterprestasi dan mengekspresikan pemahaman tentang materi yang dipelajari.

Baroody (dalam Husna, 2013) menyatakan ada dua alasan mengapa komunikasi penting dalam pembelajaran matematika, pertama karena matematika merupakan alat untuk mengkomunikasikan berbagai ide dengan jelas, tepat dan ringkas. Alasan kedua, sebagai aktivitas sosial dalam pembelajaran matematika di sekolah dimana akan terjadi interaksi antara guru dengan siswa maupun siswa dengan siswa.

Berdasarkan sumber yang diperoleh dari hasil observasi dan wawancara penulis di SMP Negeri 3 Sukasada, ditemukan beberapa masalah dalam pembelajaran matematika. Pertama, dalam kegiatan pembelajaran guru masih menggunakan model pembelajaran konvensional. Dalam memulai pembelajaran, guru biasanya menguraikan materi yang dibahas pada papan tulis dan menjelaskannya dengan metode ceramah. Kegiatan belajar seperti ini, akan membuat siswa menjadi pasif, karena pembelajaran hanya berpusat pada guru. Setelah membahas suatu materi, guru biasanya memberikan soal-soal latihan untuk memancing pertanyaan atau tanggapan siswa. Dalam pembelajaran, guru juga melakukan diskusi kelompok untuk membahas suatu materi. Akan tetapi, menurut Sukendra (2018) seorang guru matematika di Kelas VII A SMP Negeri 3 Sukasada, siswa masih belum terbiasa untuk melakukan diskusi kelompok. Kegiatan diskusi kelompok biasanya dilakukan secara individu oleh siswa dalam satu kelompok.

Kedua, siswa masih kebingungan ketika guru memberikan permasalahan. Hal ini dikarenakan, dalam kegiatan pembelajaran sehari-hari guru biasanya hanya memberikan soal-soal yang bersifat rutin, untuk membentuk pemahaman siswa terhadap materi yang dibahas. Dalam kegiatan tersebut, siswa pada umumnya memiliki kemampuan dalam penggunaan rumus-rumus dan menyelesaikan soal yang diberikan. Akan tetapi, ketika guru memberikan permasalahan sesuai dengan materi yang dibahas, siswa pada umumnya memiliki keterbatasan dalam menentukan rumus apa yang harus digunakan, konsep apa yang harus dipakai, dan bagaimana cara menyelesaikan permasalahan.

Berdasarkan masalah kedua, penulis melakukan tes awal kepada siswa di kelas bersangkutan untuk mengetahui kemampuan komunikasi matematika siswa di kelas tersebut. Materi yang diberikan adalah mengenai materi persamaan linier satu variabel yang telah dikuasai dalam pertemuan sebelumnya.

Setelah melakukan observasi awal, untuk menyakinkan dugaan peneliti bahwa kemampuan komunikasi matematis siswa masih rendah, peneliti memberikan tes kemampuan awal yang terdiri dari dua butir soal uraian dengan materi persamaan linier satu variabel yang sudah diperoleh pada pertemuan sebelumnya.

Tes awal yang dilakukan penulis diikuti oleh 32 orang siswa di Kelas VIIA SMP Negeri 3 Sukasada. Dari tes tersebut, didapat bahwa sebagian besar siswa masih memiliki kemampuan komunikasi matematika yang rendah. Hasil ini meyakinkan penulis bahwa kemampuan komunikasi matematika siswa di Kelas VIIA SMP Negeri 3 Sukasada masih tergolong rendah. Hal ini mengindikasikan bahwa proses pembelajaran yang selama ini diterapkan tidak mengasah kemampuan komunikasi matematis siswa secara optimal. Masalah seperti ini tentu tidak bisa dibiarkan terus berlanjut, mengingat bahwa dalam pembelajaran matematika kemampuan komunikasi matematis sangatlah penting. Untuk mengatasi permasalahan ini, diperlukan suatu solusi pembelajaran yang efektif, sehingga dapat meningkatkan kemampuan komunikasi matematis siswa. Pembelajaran yang sesuai untuk diterapkan dalam permasalahan ini adalah Model Pembelajaran Creative Problem Solving. Model pembelajaran Creative Problem Solving adalah suatu model pembelajaran yang lebih menekankan pada keterampilan dalam menyelesaikan suatu permasalahan yang diikuti dengan penguatan kreativitas (Pepkin, 2004). Model Pembelajaran Creative Problem Solving dipilih karena langkah-langkah pembelajarannya sesuai dengan tujuan untuk meningkatkan kemampuan 
komunikasi matematis siswa. Model Pembelajaran Creative Problem Solving juga menggunakan teknik pembelajaran kooperatif, sehingga akan membuat siswa memiliki kesempatan untuk berdiskusi dengan teman-temannya dalam membahas suatu materi tertentu. Dengan teknik pembelajaran kooperatif, siswa akan terbiasa untuk saling bertukar pengetahuan sehingga menciptakan pembelajaran yang lebih bermakna nantinya. Model Pembelajaran Creative Problem solving menekankan pada siswa sebagai pusat pembelajaran dan guru hanya bertindak sebagai fasilitator yang akan membantu siswa apabila diperlukan. Dalam komunikasi matematika, sedikitnya ada tiga indikator komunikasi matematika yang harus dicapai oleh siswa. (1) Siswa mampu mengekspresikan ide-ide matematika melalui tulisan dalam bentuk gambar, grafik, tabel, diagram, atau simbol. (2) Siswa mampu memahami dan mengevaluasi ide-ide matematika dalam bentuk tulisan. (3) Mampu menggunakan bahasa, notasi, dan satuan matematika dengan tepat.

Pencapaian pembelajaran melalui indikator dalam komunikasi matematis tersebut, sangat sesuai apabila dibelajarkan dengan model pembelajaran Creative problem solving. Model Pembelajaran Creative problem solving memiliki 4 sintaks dalam penerapannya. 1) Clarification of the problem (klarifikasi masalah), pada tahap ini, siswa diarahkan untuk menganalisa masalah dalam mendapatkan beberapa informasi yang terdapat pada permasalahan, agar siswa dapat memahami tentang penyelesaian seperti apa yang sesuai dengan masalah tersebut dan informasi yang telah didapatkan bisa dijadikan acuan untuk menentukan beberapa solusi yang memungkinkan, (2) Brainstorming (pengungkapan pendapat), siswa memberikan gagasan - gagasan mengenai beberapa alternatif solusi yang mungkin digunakan untuk menyelesaikan masalah yang diberikan, (3) Evaluation and selection (evaluasi dan pemilihan), Siswa diarahkan untuk memilih solusi yang mungkin digunakan untuk menyelesaikan suatu permasalahan dari beberapa alternatif solusi yang telah dirumuskan sebelumnya, 4) Implementation (implentasi), siswa menggunakan strategi penyelesaian yang telah dipilih untuk menemukan penyelesaian dan permasalahan yang diberikan. Creative Problem Solving sangat relevan diterapkan dalam upaya menumbuhkan aspek aspek indikator komunikasi matematis. Melalui tahapan klarifikasi masalah, siswa mampu mengekspresikan ide - ide matematis melalui tulisan dan mendemostrasikan serta menggambarkannya secara visual. Tahapan pengungkapan pendapat serta mengevaluasi dan pemilihan, mampu memotivasi siswa untuk memahami, menginterpretasikan dan mengevaluasi ide - ide matematis baik secara tulisan, maupun dalam bentuk visual lainnya. Tahapan implementasi mampu memotivasi siswa untuk menggunakan istilah, notasi notasi matematika dan struktur strukturnya untuk menyajikan ide - ide matematika. Keempat sintaks tersebut akan mengoptimalkan indikator - indikator yang terdapat dalam komunikasi matematis siswa dalam pembelajaran matematika. Sehingga dapat meningkatkan kemampuan komunikasi matematis siswa.

Penelitian ini dilaksanakan untuk mencapai beberapa tujuan untuk mencapai beberapa tujuan, yaitu mendeskrisikan kemampuan komunikasi matematis siswa setelah diterapkan model pembelajaran creative problem solving dan mendeskipsikan model pembelajaran creative problem solving yang dapat meningkatkan kemampuan komunikasi matematis siswa. Kemudian indicator keberhasilan yang digunakan dalam penelitian ini, yaitu: (1) persentase banyaknya siswa dengan komunikasi matematis berada pada kategori tuntas (skor maksimal $\leq 70$ ) meningkat dari siklus ke siklus dan banyaknya siswa yang berada dalam kategori tuntas mencapai $70 \%$ dari total keseluruhan siswa dan (2) tanggapan siswa terhadap penerapan model pembelajaran creative problem solving ditinjau dari rata - rata skor tanggapan siswa minimal dalam kategori positif. 


\section{METODE}

Desain penelitian yang digunakan adalah model Hopkins (dalam Suharsimi Arikunto, 2009:105) setiap siklus terdiri atas empat tahap yaitu perencanaan tindakan, pelaksanaan tindakan, observasi dan evaluasi, serta refleksi.

Teknik pengumpulan data yang digunakan untuk data kemampuan komunikasi matematis siswa adalah dengan tes uraian, sedangka data tanggapan siswa menggunakan angket. Pengujian ini tidak dilakukan dengan perhitungan analisis statistik, melainkan dengan analisis rasional yaitu dengan melihat kesesuaian antara tujuan dan bahan yang diajarkan untuk masing masing butirnya.

Data kemampuan komunikasi matematis siswa dianalisis dengan menentukan rata - rata skor tes dengan rumus (1).

$\bar{X}=\frac{\sum_{i=1}^{n} X_{i}}{n}$

Selanjutnya data kemampuan komunikasi matematis siswa diklarifikasikan berdasarkan Kriteria Ketuntasan Minimum (KKM). Adapun kriteria ketuntantasan belajar matematika siswa disajikan pada Tabel 1.

\begin{tabular}{ccc} 
Tabel & $\begin{array}{c}\text { 1. } \\
\text { Kemampuan } \\
\text { matematis Siswa }\end{array}$ & $\begin{array}{c}\text { Ketuntasan } \\
\text { komunikasi }\end{array}$ \\
\hline No. & Rentangan Skor & Kategori \\
\hline 1. & $70 \leq \overline{\mathrm{X}} \leq 100$ & Tuntas \\
\hline 2. & $0 \leq \overline{\mathrm{X}}<70$ & Belum Tuntas \\
\hline
\end{tabular}

Selain ditinjau dari rata - rata skor tes, dalam penelitian ini kemampuan komunikasi matematis siswa juga ditinjau dari Ketuntasan Belajar (KB)
Untuk mengetahui tanggapan siswa terhadap model pembelajaran yang diterapkan akan dilakukan dengan menentukan rata - rata tanggapan siswa dengan rumus (2)

$\bar{T}=\frac{\sum_{i=1}^{n} T_{i}}{n}$

Angket tanggapan siswa yang digunakan pada penelitian ini terdiri dari 15 butir pertanyaan. Tiap butir pertanyaan mempunyai skor maksimal 5 dan minimal 1 , sehingga skor tertinggi ideal adalah 75 dan skor terendal ideal adalah 15. Kriteria penggolongan rata rata skor tanggapan siswa disajikan pada Tabel 2.

Tabel 2. Kualifikasi Tanggapan Siswa

\begin{tabular}{|c|c|}
\hline Rentangan Skor & Kriteria \\
\hline $\bar{T} \geq 63$ & Sangat Positif \\
\hline $51 \leq \bar{T}<63$ & Positif \\
\hline $39 \leq \bar{T}<51$ & Cukup \\
\hline $27 \leq \bar{T}<39$ & Kurang \\
\hline $\bar{T}<27$ & Sangat Kurang \\
\hline
\end{tabular}

\section{HASIL DAN PEMBAHASAN Hasil Refleksi Awal}

Tes awal diberikan untuk memperoleh gambaran yang lebih jelas mengenai permasalahan dalam pembelajaran matematika yang terjadi di kelas tersebut.

Hasil analisis data kemampuan komunikasi matematis yang dimiliki siswa sebelum pelaksanaan tindakan memperlihatkan bahwa nilai terendah adalah 12,5 dan nilai tertinggi adalah 70,83 . Persentase banyaknya siswa yang nilai tes awalnya belum tuntas adalah $87,5 \%$ yaitu orang, sedangkan persentase banyaknya siswa yang nilai tes awalnya sudah tuntas adalah $12,5 \%$ yaitu 4 orang. Sebaran ketuntasan hasil tes awal kemampuan komunikasi matematis siswa sebelum pelaksanaan tindakan penelitian disajikan dalam Gambar 1 


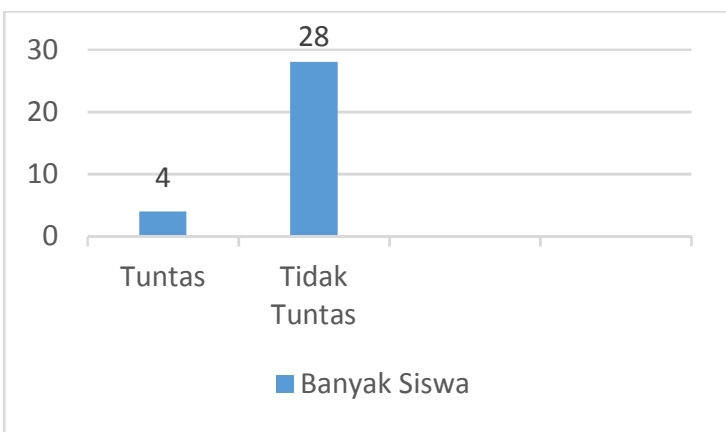

Gambar 1. Grafik sebaran hasil tes awal komunikasi matematis siswa

\section{Hasil Penelitian Pada Siklus I}

Pada akhir siklus I, siswa diberikan tes kemampuan komunikasi matematis yang terdiri dari tiga soal uraian. Dari analisis data yang dilakukan, diperoleh bahwa rata - rata nilai kemampuan komunikasi matematis siswa sebesar 48 dan ketuntasan belajar siswa sebesar $21,875 \%$. Dilihat dari persentase ketuntasan belajar siswa hanya 7 orang dari 32 siswa yang mampu mendapatkan nilai dengan kategori tuntas. Dapat dilihat pada gambar 2 yang telah diberikan

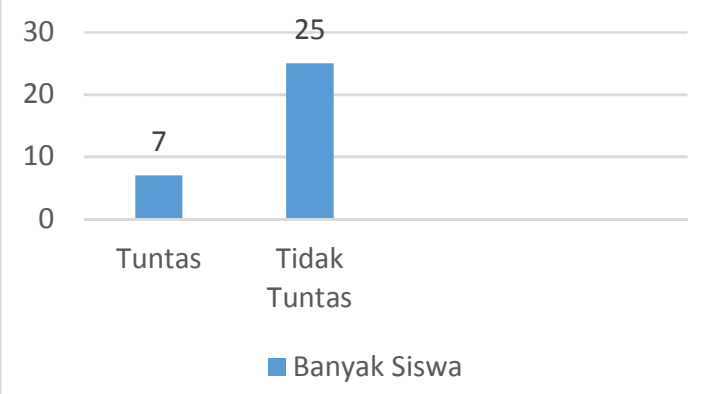

Gambar 2. Sebaran Hasil Tes Kemampuan Komunikasi Matematis Siklus I

Meskipun data rata - rata nilai kemampuan komunikasi matematis dan ketuntasan belajar siswa secara klasikal pada siklus I belum memenuhi standar indicator keberhasilan yang ditetapakan, namun jika dibandingkan dengan dengan data yang didapat pada tahap tes awal terlihat sudah terdapat peningkatan. Hasil siklus I menjadi acuan bahwa perlu adanya refleksi dan perbaikan pada siklus selanjutnya.

\section{Hasil Pada siklus II}

Pada akhir siklus II, siswa diberikan tes kemampuan penalaran matematis yang terdiri dari empat soal uraian. Dari analisis data yang dilakukan, diperoleh bahwa ratarata nilai keamampuan komunikasi matematis siswa sebesar 58,20 dan ketuntasan belajar sebesar 46,875\%. Dilihat dari persentase ketuntasan belajar siswa hanya 15 orang dari 32 siswa yang mampu mendapatkan nilai dengan kategori tuntas. Dapat dilihat pada gambar 3 yang telah diberikan

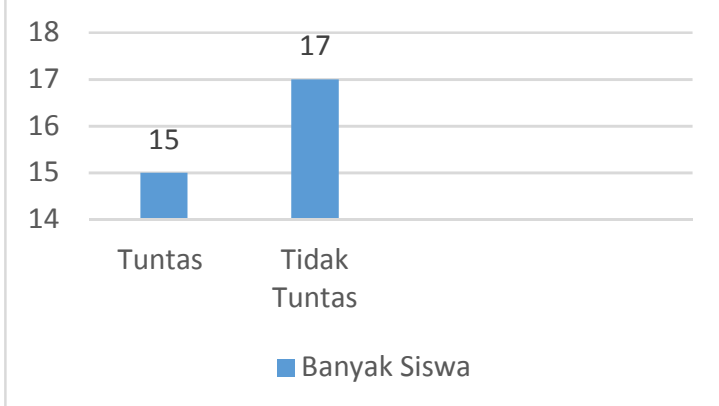

Gambar 3. Sebaran Hasil tes Kemampuan Komunikasi Matematis Siklus II

Meskipun data rata - rata nilai kemampuan komunikasi matematis dan ketuntasan belajar siswa secara klasikal pada siklus II masil juga belum memenuhi standar indikator keberhasilan yang ditetapakan, namun jika dibandingkan dengan dengan data yang didapat pada tahap tes siklus I sudah terdapat peningkatan. Hasil siklus II menjadi acuan bahwa perlu adanya refleksi dan perbaikan pada siklus selanjutnya.

\section{Hasil Pada siklus III}

Pada akhir siklus III, siswa diberikan tes kemampuan penalaran matematis yang terdiri dari empat soal uraian. Dari analisis data yang dilakukan, diperoleh bahwa ratarata nilai keamampuan komunikasi matematis siswa sebesar 70,737 dan ketuntasan belajar sebesar $75 \%$. Dilihat dari persentase ketuntasan belajar siswa hanya 24 orang dari 32 siswa yang mampu mendapatkan nilai dengan kategori tuntas. Dapat dilihat pada gambar 4 yang telah diberikan 


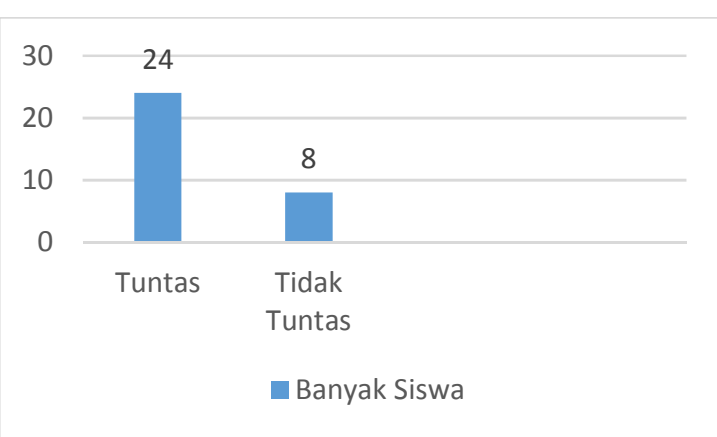

Gambar 3. Sebaran Hasil tes Kemampuan Komunikasi Matematis Siklus III

Pada pelaksanaan tindakan siklus III sudah memenuhi indikator keberhasilan yaitu rata - rata nilai kemampuan komunikasi matamatis siswa minimal mencapai yaitu sebesar 70 dengan ketuntasan belajar siswa secara klasikal minimal $70 \%$. Kemudian rata - rata nilai kemampuan komunikasi matematis siswa dan ketuntasan belajar secara klasikal tersebut telah meningkat dari siklus I dan siklus II.

\section{Peningkatan Kemampuan Komunikasi Matematis Siswa}

Ringkasan hasil pelaksanaan test kemampuan komunikasi matematis yang diperoleh siswa sejak pemberian tes awal, siklus I, siklus II, dan siklus III disajikan pada tabel 3

Tabel 3. Ringkasan Data

Komunikasi Matematis Siswa

\begin{tabular}{llll}
\hline Tahap & $\begin{array}{l}\text { Rata } \\
\text { rata } \\
\text { Nilai }\end{array}$ & $\begin{array}{l}\text { Ketuntasan } \\
\text { Belajar }\end{array}$ & Kategori \\
\hline $\begin{array}{l}\text { Tes } \\
\text { Awal }\end{array}$ & 27,001 & $12,50 \%$ & $\begin{array}{l}\text { Belum } \\
\text { Tuntas }\end{array}$ \\
\hline Siklus I & 48 & $21,87 \%$ & $\begin{array}{l}\text { Belum } \\
\text { Tuntas }\end{array}$ \\
\hline Siklus II & 58 & $46,87 \%$ & $\begin{array}{l}\text { Belum } \\
\text { Tuntas }\end{array}$ \\
\hline Siklus III & 71 & $75 \%$ & Tuntas \\
\hline
\end{tabular}

Berdasarkan Tabel 3, secara umum terlihat bahwa kemampuan komunikasi matematis yang dimiliki oleh siswa telah mengalami peningkatan. Terlihat juga bahwa indicator pada pelaksanaan siklus III.

\section{Pembahasan}

Berdasarkan penelitian yang telah dilaksanakan selama 3 siklus telah menunjukkan tercapainya peningkatan kemampuan komunikasi matematis yang dimiliki siswa. Hal ini terlihat dari refleksi siklus. Adapun hal - hal yang menyebabkan terjadinya peningkatan komunikasi matematis siswa adlah sebagai beriku. Pertama, pada tahap evaluasi dan pemilihan siswa dilatih untuk mengungkapkan pendapatnya ke dalam diskusi kelompok. Hal ini membuat siswa yang pada awalnya hanya mengandalkan guru dalam memperoleh informasi semakin mandiri dalam memperoleh informasi yang dapat dijadikan suatu strategi penyelesaian masalah. Diskusi dalam kelompok memotivasi siswa untuk lebih berani mengemukakan pendapatnya dalam kelompok kecil. Selain pertukaran ide untuk mampu menyelesaikan permasalahan, hal ini akan melatih siswa untuk mampu menyampaikan ide mereka dengan baik. Siswa berlatih menyampaikan ide agar dapat dipahami oleh teman dalam kelompoknya. Pembelajaran berlangsung lebih bermakna karena siswa dapat mengeksplorasi pengetahuan dan membangun pemahaman sesuai dengan pengalaman yang dimilikinya.

Kedua, siswa dalam kelompoknya dilatih untuk menganalisa informasi yang telah diperoleh serta mengevaluasi ide dan gagasan berdasarkan informasi tersebut. Guru memastikan setiap kelompok bersungguh-sungguh dalam melaksanakan diskusi dan tidak hanya mengandalkan satu orang. Siswa diberikan kesempatan untuk berlatih menuliskan konsep matematika dengan bahasa sendiri. Guru mengarahkan perwakilan kelompok untuk memaparkan hasil kerja kelompoknya, hal ini memotivasi siswa untuk berani berpendapat dan mampu menuliskan ide mereka secara matematis. Pada akhir tahap implementasi, guru menekankan hal-hal penting dari konsep yang dibahas.

Ketiga, guru memperbanyak latihan soal sehingga siswa banyak berlatih dalam mengekspresikan dan menuliskan ide yang mereka miliki. Siswa akan mampu mengkomunikasikan ide matematis dengan baik apabila secara kontinu berlatih melalui latihan soal. Hal ini akan memperkuat kemampuan komunikasi 
matematis siswa apabila telah terbiasa menuliskan penyelesaian secara matematis. Selama proses pembelajaran guru lebih menekankan pada pengekspresian ide-ide matematis. Hal ini dilakukan dengan memberikan pertanyaan pengarah bagi siswa yang mengalami kesulitan sehingga siswa akan membangun logika berpikirnya secara mendiri dan mampu mengkomunikasikan idenya secara matematis

Penelitian yang sejalan dengan hal ini adalah penelitian yang dilakukan oleh Karsana, (2016). Hasil dari penelitian ini adalah kemampuan berpikir kritis siswa pada kelas eksperimen lebih baik dari pada kemampuan berpikir kritis siswa pada kelas kontrol dengan penerapan model pembelajaran CPS dengan pembangkitan rasa jengah pada kelas eksperimen dan penerapan model konvensional atau model pembelajaran yang biasa digunakan oleh guru pada kelas kontrol. Pramartha, (2015). Hasil dari penelitian ini adalah model pembelajaran CPS dengan bantuan alat peraga geometris berpengaruh positif terhadap kemampuan operasi bentuk aljabar siswa. Novianti, (2017). Hasil dari penelitian ini adalah model pembelajaran yang diterapkan terhadap pemecahan masalah matematika siswa menunjukkan bahwa model pembelajaran CPS berbantuan video animasi sparkol berkontribusi positif terhadap pemecahan masalah matematika siswa. Dewi (2018). Hasil dari penelitian ini adalah model Creative Problem Solving (CPS) berpengaruh positif terhadap kemampuan pemecahan masalah matematika matematika peserta didik. Selain terjadi peningkatan komunikasi matematis yang dimiliki siswa, penerapan model Pembelajaran Creative Problem Solving dalam pembelajaran matematika juga mendapatkan tanggapan positif dari siswa.

Selain terjadi peningkatan kemampuan penalaran matematis siswa dari siklus ke siklus, dengan penerapan pendekatan Creative Problem Solving ini juga mendapatkan tanggapan positif dari siswa. Dengan demikian, hasil penelitian ini telah memenuhi semua indikator keberhasilan yang telah ditetapkan. Jadi dapat disimpulkan penelitian telah berhasil.

\section{SIMPULAN DAN SARAN Simpulan}

Berdasarkan hasil penelitian dan pembahasan yang telah dipaparkan pada bab sebelumnya, dapat disimpulkan beberapa hal sebaga berikut.

Pertama, penerapan model pembelajaran Creative Problem Solving dapat meningkatkan kemampuan komunikasi siswa. Hal ini dapat dilihat dari ketuntasan belajar siswa yang telah meningkat dari siklus ke siklus dan mencapai indikator keberhasilan yang ditetapkan. Ketuntasan belajar siswa pada siklus I, siklus II, dan siklus III berturut-turut yaitu $21,87 \%, 46,87 \%, 75 \%$. Peningkatan tersebut terjadi selama pelaksanaan pembelajaran pada setiap siklus. Pada siklus I, siswa masih belum aktif melakukan diskusi dengan kelompoknya dan bertanya kepada guru untuk menyelesaikan permasalahan. Meskipun begitu terdapat beberapa siswa pula yang terlibat aktif dalam diskusi kelompoknya. Pada siklus II, siswa sudah terbiasa melakukan diskusi kelompok, meskipun hanya didominasi oleh beberapa siswa dan beberapa pendapat yang disampaikan siswa kurang tepat, siswa telah menunjukkan peningkatan karena telah berani berpendapat dan mempresentasikan idenya. Pada siklus III, siswa sudah terbiasa dengan pembelajaran yang diterapkan yakni berdiskusi kelompok, dimana didalam diskusi tersebut ada beberapa tahapan yang harus dijalani yakni klarifikasi masalah, pengungkapan. pendapat, evaluasi dan seleksi, serta implementasi. Guru memperbanyak latihan soal sehingga siswa terlatih untuk menuliskan idenya secara matematis. Meskipun beberapa pendapat siswa masih kurang tepat, siswa terlihat antusias dan terlibat aktif dalam diskusi dan mempresentasikan hasil kerjanya sehingga berdampak pada meningkatnya kemampuan komunikasi matematis siswa.

Kedua, tanggapan siswa terhadap penerapan model pembelajaran Creative Problem Solving ditinjau dari rata-rata skor angket tanggapan siswa berada pada kategori positif dengan rata-rata sebesar 55,53 


\section{Saran}

Berdasarkan temuan-temuan yang diperoleh selama melaksanakan penelitian ini, dapat diajukan beberapa saran sebagai berikut:

Pertama, Bagi guru yang mengalami permasalahan terkait rendahnya kemampuan komunikasi matematika siswa dapat menerapkan model pembelajaran Creative Problem Solving sebagai salah satu alternatif dalam menyelesaikan permasalahan tersebut. Guru matematika yang mengalami permasalahan serupa dapat mencoba menerapkan model pembelajaran ini pada pokok bahasan yang lain.

Kedua, Bagi pembaca yang tertarik untuk melakukan penelitian lebih lanjut mengenai penerapan model pembelajaran Creative Problem Solving agar memperhatikan kendala-kendala yang dialami peneliti selama pelaksanaan penelitian sebagai pertimbangan untuk perbaikan, penyempurnaan, dan optimalisasi pelaksanaan penelitian.

\section{DAFTAR PUSTAKA}

Arikunto, Suharsimi. 2009. Dasar-Dasar Evaluasi Pendidikan. Jakarta. Bumi Aksara.

Candiasa, I M. 2010. Statistik Univariat dan Bivariat disertai Aplikasi SPSS. Singaraja:UNDIKSHA.

Candiasa, I.M. 2010. Pengujian Instrumen Penelitian Disertai Aplikasi ITEMAN dan BIGSTEPS. Singaraja: Unit Penerbitan Universitas Pendidikan Ganesha.

Dewi, Ni Kadek Mena Sinta. 2018."peningkatan kemampuan pemecahan masalah matematika siswa kelas VIII-A di SMP Negeri 1 Sawan melalui penerapan model pembelajaran Creative Problem Solving(CPS) berbantuan portofolio". Skripsi(tidak diterbitkan). Jurusan Pendidikan Matematika, Universitas Pendidikan Ganesha.

Husna, dkk. 2013. "Peningkatan Kemampuan Pemecahan Masalah dan Komunikasi Matematis Siswa
Sekolah Menengah Pertama Melalui Model Pembelajaran Kooperatif Tipe Think-Pair-Share (TPS)". Jurnal Peluang, Volume 1, Nomor 2 (hlm. 81--92).

Karsana, Putu Yudi. 2016. "Pengaruh Model Pembelajaran Creative Problem Solving (CPS) dengan Pembangkitan Rasa Jengah terhadap Kemampuan Berpikir Kritis Matematis Siswa Kelas VIII di SMP Negeri 1 Banjar". Skripsi (tidak diterbitkan). Jurusan Pendidikan Matematika, Universitas Pendidikan Ganesha.

Novianti, Luh Putu. 2017. "Studi Kuantitatif dan Kualitatif tentang pengaruh model pembelajaran creative problem solving berbantuan video animasi sparkol terhadap kemampuan pemecahan masalah matematika siswa kelas VII SMP Negeri 2 Singaraja". Skripsi (tidak diterbitkan). Jurusan Pendidikan Matematika, Universitas Pendidikan Ganesha.

Pepkin. 2004. Creative Problem Solving in Math. Tersedia di : http//www/uh.edu.hti/w/2004/v02/04. html./ (diakses 3 Desember 2018)

Pramartha, I Nyoman Bagus. 2015. "Pengaruh Penerapan Model Pembelajaran Creative Problem Solving (CPS) dengan Berbantuan Alat Peraga Geometris terhadap Peningkatan Kemampuan Operasi Bentuk Aljabar Siswa Kelas VII SMP Negeri 2 Singaraja". Skripsi (tidak diterbitkan). Jurusan Pendidikan Matematika, Universitas Pendidikan Ganesha

Ramdani, Yani. 2012. "Pengembangan Instrumen dan Bahan Ajar untuk Meningkatkan Kemampuan Komunikasi, Penalaran, dan Koneksi Matematis dalam Konsep Integral". Jurnal Penelitian Pendidikan, Volume 13, Nomor 1 (hlm. 44-52). 